\title{
DEVELOPMENT OF PRIMARY OPEN-ANGLE GLAUCOMA AND DELETION POLYMORPHISM OF THE GLUTATHIONE-S-TRANSFERASE GENES
}

\author{
Artem Burdei \\ Department of ophthalmology \\ Shupyk National Medical Academy of Postgraduate Education \\ 9 Dorohozytska str., Kyiv, Ukraine, 04112 \\ artemb2006@ukr.net
}

\begin{abstract}
The aim of the research. To investigate the association of the development of primary open-angle glaucoma with deletion polymorphism of glutathione-S-transferase genes.

Materials and methods. Under our observation there were 172 patients, residents of Ukraine with primary open-angle glaucoma I-IV stages. Analysis of the deletion polymorphism of GSTM1 and GSTT1 genes was performed by real-time polymerase chain reaction using unified TaqMan Mutation Detection Assays Life-Technology (USA) test systems. Statistical analysis of the obtained data was performed using the MedStat package and the statistical package MedCalc v.15.1 (MedCalc Software bvba).

Results and discussion. The detection of null alleles of the GSTM1 gene was observed in $39 \%$ of patients in the control group, in patients with POAG a significant increase in the frequency of deletion polymorphism to $50-56 \%$ was observed with the progression of the disease in stages II-IV. In patients with stage IV disease, the effect of the zero GSTM1-null allele on POAG course was determined $\left(\chi^{2}=3.97 ; \mathrm{p}=0.047\right)$, and the null allele of GSTM1 doubled the probability of developing the disease $(\mathrm{OR}=2.01 ; 95 \% \mathrm{CI}=1.01-4.01)$ in patients of group 4 compared with control. The null allele of the GSTT1 gene in the control group was found in $31 \%$, an increase in the frequency of the GSTT1-null allele was also observed in the second and fourth stages of POAG from $41 \%$ to $54 \%$. Statistically significant differences of GSTT1 gene allele frequencies were determined between the control group and all patients with POAG $\left(\chi^{2}=4.43\right.$; $\mathrm{p}=0.03)$, between the control and the 4th group $\left(\chi^{2}=7.64 ; \mathrm{p}=0.01\right)$, and between the 1 st and 4 th groups $\left(\chi^{2}=5.52 ; \mathrm{p}=0.02\right)$. An association with the development of POAG $\left(\chi^{2}=4.43 ; \mathrm{p}=0.03\right)$ was determined for the deletion polymorphism of the GSTT1 gene when comparing the control group with the data of all patients with POAG (1-4 groups). At stratification by stages of POAG (that is, by groups of patients), an association with the development of POAG was determined only in patients of group $4\left(\chi^{2}=7.64 ; p=0.01\right)$ compared with the control group.

Conclusions. The association of the null allele of the GSTT1 gene with POAG was established $(\mathrm{p}=0.03)$. The presence of the GSTT1-null allele significantly increased the risk of developing POAG (OR=1.75; $\mathrm{BI}=1.04-2.96$ ) compared with the control group. The presence of null alleles (GSTM1-null and GSTT1-null) of the GST deletion polymorphism significantly increased the risk of stage IV POAG $(\mathrm{OR}=2.01 ; \mathrm{BI}=1.01-4.01$ and $\mathrm{OR}=2.66$; $\mathrm{VI}=1.32-5.37$, respectively $)$ compared with the control group, which indicated the effect of zero alleles on the rapid progression of the disease.
\end{abstract}

Keywords: primary open-angle glaucoma, development, glutathione-S-transferase gene polymorphism (GSTM1 and GSTT1).

DOI: $10.21303 / 2504-5679.2020 .001289$

\section{Introduction}

Primary open-angle glaucoma (POAG) is widespread worldwide (accounting for $74 \%$ in the overall structure of glaucoma) and in Ukraine (17.2\% in the general structure of vision pathology) $[1,2]$. The main problem is the lack of timely diagnosis, and therefore the effective treatment of the initial stages of glaucoma. POAG results in both reduced visual acuity and complete blindness. According to WHO, glaucoma ranks second among the diseases that are irreversibly cause blindness and ranges from $0.6 \%$ to $33.0 \%[3,4]$.

It has long been believed that in the pathogenesis of this disease the leading place is occupied by an increase in intraocular pressure (IOP), but at the present stage POAG is attributed to multifactorial diseases $[5,6]$. The risk factors for its development include: hypertension, smoking, diabetes, myopia, old age, hypothyroidism, dyscirculatory encephalopathy $[7,8]$. In the pathogenesis of POAG, the activation of oxidative stress and glutamate excitotoxicity, which damage the retinal ganglion cells, endothelium, activate apoptosis, and impaired blood rheological properties and microcirculation, play a significant role $[8,9]$. 
In recent years, the evidence base for the involvement of hereditary factors has increased, and although POAG is not inherited by Mendel's law, the risk of its development is significantly increased in offspring of patients with POAG $[10,11]$. The association of 25 genes with the development of the glaucomatous process has been determined [12, 13]. Particular attention is paid to genes that are related to the regulation of the processes of elimination of toxic substances and protection against oxidative damage. Such genes include genes that regulate glutathione-S-transferase (GST) synthesis. The family of these enzymes has eight classes: Alpha (GSTA), Mu (GSTM), Pi (GSTP), Theta GSTT), Kappa (GSTK), Zeta (GSTZ), Omega (GSTO) and Sigma (GSTS) [14, 15]. GST enzymes catalyze the conjugation of reduced glutathione, protect the body against toxic substances, reduce endogenous oxidative stress, and neutralize lipid and nucleic acid oxidation products [16]. It has been determined that the enzymatic activity of transcriptional proteins and GST directly depends on the deletion polymorphism of GSTM1 and GSTT1 genes, which are regulators of second-phase xenobiotics biotransformation enzymes [17, 18].

The aim of the research. To investigate the association of the development of primary open-angle glaucoma with deletion polymorphism of glutathione-S-transferase genes.

\section{Materials and methods}

The study involved 172 patients with stage I-IV POAGs and various levels of IOP, who were examined at the Kyiv City Clinical Ophthalmic Hospital Center for Eye Microsurgery, the clinical base of the Shupyk National Medical Academy of Postgraduate Education. Used the classification of primary glaucoma A. P. Nesterov and A. Ya. Bunin (1976) and the classification of perimetric changes according to the stages of glaucoma. In the initial examination, patients were divided into four groups: group 1 - patients with initial stage POAG, group 2 - with advanced POAG, group 3 - with further progression and narrowing of the visual field, group 4 - terminal, with the development of blindness.

The studies were conducted in compliance with the main provisions of the Council of Europe Convention on Human Rights and Biomedicine, the World Health Association Helsinki Declaration on Ethical Principles for Scientific Research with Human Involvement (1975, with further additions, including 1983 version) and MOH Order No. 690. All patients were familiarized with the purpose and objectives of the study. The control group consisted of 98 healthy volunteers who had no history of glaucoma disease.

Samples of venous blood were collected for molecular genetic studies. Deletion polymorphism analysis of GSTM1 and GSTT1 genes was performed using real-time polymerase chain reaction (PCR) using unified TaqMan Mutation Detection Assays LifeTechnology (USA) test systems in the Gene Amp® PCR System 7500 automatic amplifier (USA). Statistical analysis of the obtained data was performed using the MedStat package and the statistical package MedCalc v.15.1 (MedCalc Software bvba). The largest odds ratio (OR) was determined by the association of alleles or genotypes with a tendency to glaucoma. In all cases, the level of statistical significance was assumed to be $95 \%(\mathrm{p}<0.05)$.

\section{Results}

The allelic polymorphism of the GSTM1 and GSTT1 genes in the control group and in patients with POAG was represented by the variants: homozygote 0/0 (null alleles), which completely deprives the enzyme of its activity, and heterozygote $+/ 0$. They are characterized by reduced enzymatic activity (so-called "slow conjugators") and homozygotes $+/+$ that have normal glutathione transferase activity (a functionally active enzyme is synthesized). Therefore, the presence of zero alleles causes a decrease in enzyme activity and, accordingly, a failure of the body's detoxification system [18].

The distribution of alleles of the GSTM1 gene in the control group and in patients of different groups is given in Table $\mathbf{1 .}$

Detection of null alleles of the GSTM1 gene was observed in $39 \%$ of patients in the control group. In patients with POAG, a significant increase in the incidence of deletion polymorphism by up to $50-56 \%$ was observed in the progression of the disease in stages II-IV. 
Genes regulators of enzymes of the second phase of biotransformation of xenobiotics provide protection of the body against endogenous oxidative stress, exogenous toxins and neutralize lipid and nucleic acid oxidation products [16, 19]. Insufficiency of antioxidant protection systems in eye tissues, first of all - reduced glutathione, leads to intensification of oxidative stress with further development of neurodegeneration and apoptosis of retinal ganglion cells [20].

Our studies (Table 2) determined the effect of the GSTM1-null null allele on the POAG course $\left(\chi^{2}=3.97 ; p=0.047\right)$, which was observed in patients with stage IV disease compared with the control group. In our opinion, this could be evidence of potentiation of disease progression in carriers of the GSTM1-null null allele.

Table 1

Distribution of GSTM1 gene allele frequency between groups

\begin{tabular}{|c|c|c|c|c|c|c|}
\hline \multicolumn{2}{|c|}{ Alleles } & \multirow{2}{*}{$\begin{array}{c}\text { Control } \\
60\end{array}$} & \multirow{2}{*}{$\begin{array}{c}\text { Group } 1 \\
23\end{array}$} & \multirow{2}{*}{$\begin{array}{c}\text { Group } 2 \\
22\end{array}$} & \multirow{2}{*}{$\begin{array}{c}\text { Group } 3 \\
18\end{array}$} & \multirow{2}{*}{$\begin{array}{c}\text { Group } 4 \\
22\end{array}$} \\
\hline & $\mathrm{N}$ & & & & & \\
\hline G & $\%$ & 61 & 61 & 50 & 45 & 44 \\
\hline \multirow{2}{*}{ GSTM1-null } & $\mathrm{N}$ & 38 & 15 & 22 & 22 & 28 \\
\hline & $\%$ & 39 & 39 & 50 & 55 & 56 \\
\hline Total & $\mathrm{N}$ & 98 & 38 & 44 & 40 & 50 \\
\hline
\end{tabular}

Table 2

Statistical significance of differences in the distribution of GSTM1 alleles between case-control groups

\begin{tabular}{ccccc}
\hline Control, group & Cases, group & $\chi^{2}$ & df & $\mathbf{p}_{\left(\chi^{2}\right)}$ \\
\hline 0 & $1+2+3+4$ & 3.49 & 1 & 0.06 \\
0 & 1 & 0.05 & 1 & 0.94 \\
0 & 2 & 1.56 & 1 & 0.21 \\
0 & 3 & 3.04 & 1 & 0.08 \\
0 & 4 & 3.97 & 1 & 0.047 \\
1 & 2 & 0.91 & 1 & 0.34 \\
1 & 3 & 1.88 & 1 & 0.17 \\
2 & 4 & 2.36 & 1 & 0.12 \\
2 & 3 & 0.21 & 1 & 0.65 \\
& 4 & 0.39 & 1 & 0.56
\end{tabular}

Note: $\chi^{2}$-Pearson's $\chi^{2}$-square test; $d f$ - number of freedom degrees; $p_{\left(\chi^{2}\right)}$ - statistical significance of differences (if less than 0.05 differences are significant)

Determining the magnitude of the odds ratio (OR), which characterizes the strength of the association with POAG (Table 3), showed that the null allele of GSTM1 doubled the likelihood of developing the disease $(\mathrm{OR}=2.01 ; 95 \% \mathrm{BI}=1.01-4,01)$ in patients of the 4 th group in comparison with the control.

The null allele of the GSTT1 gene in the control group was found in $31 \%$, an increase in the frequency of the GSTT1-null allele was also observed in stage II-IV POAG from $41 \%$ to $54 \%$ (Table 4).

The calculation of the frequencies of alleles of the GSTT1 gene in the control and experimental groups are given in Table 5, where identified statistically significant differences between 
the control group and all patients with POAG $\left(\chi^{2}=4.43 ; \mathrm{p}=0.03\right)$, between the control and 4 groups $\left(\chi^{2}=7.64 ; \mathrm{p}=0.01\right)$ and between the 1 st and 4th groups $\left(\chi^{2}=5.52 ; \mathrm{p}=0.02\right)$. The GSTM1-null (0.39) zero allele frequencies found in our study are the same, and the GSTT1-null (0.31) frequencies are slightly higher in the European population according to 1000 Genomes Project Phase 3 (http:// www.internationalgenome.org/home). The frequency of the zero allele of the GSTM1 gene varies from $40 \%$ to $60 \%$ depending on the population and ethnic group. In Europe, the GSTT1 deletion polymorphism is found in $20 \%$ of the population [15].

Table 3

Statistical significance of differences in GSTM1 gene allele frequency distribution between control group and group 4 and their degree of association with POAG

\begin{tabular}{ccccccc}
\hline Alleles & Group $\mathbf{4} \mathbf{n}=\mathbf{5 0}$ & Control $\mathbf{n = 9 8}$ & $\chi^{2}$ & $\mathbf{p}_{\left(\chi^{2}\right)}$ & OR & $\mathbf{1 9 5} \% \mathbf{B I}$ \\
\hline GSTM1+ & 0.44 & 0.61 & 3.97 & 0.047 & 0.50 & $0.25-0.99$ \\
GSTM1-null & 0.56 & 0.39 & & 2.01 & $1.01-4.01$
\end{tabular}

Note: $\chi^{2}$-Pearson's $\chi^{2}$-square test; $p_{\left(\chi^{2}\right)}$ statistical significance of differences (ifless than 0.05 differences are significant); OR - odds ratio; $\pm 95 \% B I- \pm 95 \%$ probable interval for the OR value

Table 4

Frequency distribution of GSTT1 gene alleles between groups

\begin{tabular}{ccccccc}
\hline \multicolumn{1}{c}{ Alleles } & & Control & Group 1 & Group 2 & Group 3 & Group 4 \\
\hline \multirow{2}{*}{ GSTT1+ } & $\mathrm{N}$ & 68 & 27 & 26 & 21 & 23 \\
& $\%$ & 69 & 71 & 59 & 53 & 46 \\
GSTT1-null & $\mathrm{N}$ & 30 & 11 & 18 & 19 & 27 \\
Total & $\%$ & 31 & 29 & 41 & 47 & 54 \\
& $\mathrm{~N}$ & 98 & 38 & 44 & 40 & 50
\end{tabular}

Table 5

Statistical significance of differences in the distribution of GSTT1 alleles between "case-control" groups

\begin{tabular}{ccccc}
\hline Control, group & Cases, group & $\chi^{2}$ & df & $\mathbf{p}_{\left(x^{2}\right)}$ \\
\hline 0 & $1+2+3+4$ & 4.43 & 1 & 0.03 \\
0 & 1 & 0.04 & 1 & 0.85 \\
0 & 2 & 1.43 & 1 & 0.23 \\
0 & 3 & 3.53 & 1 & 0.06 \\
0 & 4 & 7.64 & 1 & 0.01 \\
1 & 2 & 1.27 & 0.26 \\
1 & 3 & 2.83 & 1 & 0.09 \\
2 & 4 & 5.52 & 1 & 0.02 \\
2 & 3 & 0.37 & 1 & 0.54 \\
3 & 4 & 1.61 & 1 & 0.20
\end{tabular}

Note: $\chi^{2}$ - Pearson's $\chi^{2}$-square test; $d f$ - number of freedom degrees; $p_{\left(\chi^{2}\right)}$ - statistical significance of differences (if less than 0.05 differences are significant)

An association with the development of POAG $\left(\chi^{2}=4.43 ; p=0.03\right)$ was determined for the deletion polymorphism of the GSTT1 gene (Table 6) when comparing the control group with the data of all patients with POAG (groups 1 to 4). 
At stratification by stages of POAG (that is, by groups of patients), an association with the development of POAG was determined (Table 7) only in patients of group $4\left(\chi^{2}=7.64 ; p=0.01\right)$ compared with the control group.

Table 6

Statistical significance of differences in GSTT1 gene allele frequency distribution between control group and patients with POAG and their degree of association with POAG

\begin{tabular}{ccccccc}
\hline Alleles & POAG $\mathbf{n}=\mathbf{1 7 2}$ & Control $\mathbf{n}=\mathbf{9 8}$ & $\chi^{2}$ & $\mathbf{p}_{\left(\chi^{2}\right)}$ & OR & $\mathbf{1 9 5} \% \mathbf{B I}$ \\
\hline GSTT1+ & 0.56 & 0.69 & 4.43 & 0.03 & 0.57 & $0.34-0.96$ \\
GSTT1-null & 0.44 & 0.31 & & & 1.75 & $1.04-2.96$
\end{tabular}

Note: $\chi^{2}$ - Pearson's $\chi^{2}$-square test; $p_{\left(x^{2}\right)}$-statistical significance of differences (if less than 0.05 differences are significant); OR odds ratio; $\pm 95 \% \mathrm{BI}- \pm 95 \%$ probable interval for the OR value

Table 7

Statistical significance of differences in GSTT1 gene allele frequency distribution between control and group 4 patients and their degree of association with POAG

\begin{tabular}{ccccccc}
\hline Alleles & Group $\mathbf{4} \mathbf{n}=\mathbf{5 0}$ & Control $\mathbf{n}=\mathbf{9 8}$ & $\boldsymbol{\chi}^{\mathbf{2}}$ & $\mathbf{p}_{\left(\chi^{2}\right)}$ & OR & $\pm \mathbf{9 5} \mathbf{\%}$ BI \\
\hline GSTT1+ & 0.46 & 0.69 & 7.64 & 0.01 & 0.38 & $0.19-0.76$ \\
GSTT1-null & 0.54 & 0.31 & & & 2.66 & $1.32-5.37$
\end{tabular}

Note: $\chi^{2}$ - Pearson's $\chi^{2}$-square test; $p_{\left(\chi^{2}\right)}$-statistical significance of differences (if less than 0.05 differences are significant); OR odds ratio; $\pm 95 \% \mathrm{BI}- \pm 95 \%$ probable interval for the OR value

\section{Discussion}

Studies that considered POAG in different ethnic groups have suggested that deletion polymorphisms of GSTM1 and GSTT1 can either increase or decrease the risk of POAG or do not confirm any association with the disease [16]. The obtained data in our study indicated that there was a negative association of GSTT1 and GSTM1 deletion polymorphisms with the development of POAG. It is likely that the accumulation of toxic metabolites in the eye tissues due to a decrease in glutathione transferase activity contributes to tissue damage and leads to a deepening of the drainage of the aqueous humour of the eye.

Study limitations. The study was not conducted in case of identified concomitant pathology of eyes or another organs.

Perspective of further research. Determination of the role of deletion polymorphism of glutathione-S-transferase genes in POAG development and progression will provide an opportunity to evaluate the risk of POAG development and it's stages depending on the relevant genotype. As a result of the research, a mathematical model will be designed and can be used in practical ophthalmology to determine an individual treatment strategy of POAG.

\section{Conclusions}

The association of the zero allele of the GSTT1 gene with the development of primary open-angle glaucoma $(\mathrm{p}=0.03)$ was established.

The presence of the GSTT1-null allele significantly increased the risk of developing POAG $(\mathrm{OR}=1.75 ; \mathrm{CI}=1.04-2.96)$ compared with the control group

The presence of null alleles (GSTM1-null and GSTT1-null) of the deletion polymorphism of the GST gene significantly increased the risk of stage IV POAG $(\mathrm{OR}=2.01 ; \mathrm{BI}=$ $=1.01-4.01$ and $\mathrm{OR}=2.66 ; \mathrm{BI}=1.32-5.37$, respectively) compared with the control group, which indicated the effect of zero alleles on the rapid progression of the disease.

\section{Conflict of interest}

The authors declare there is no conflict of interest. 


\section{References}

[1] Tham, Y.-C., Li, X., Wong, T. Y., Quigley, H. A., Aung, T., Cheng, C.-Y. (2014). Global prevalence of glaucoma and projections of glaucoma burden through 2040: a systematic review and meta-analysis. Ophthalmology, 121, 2081-2090. doi: http://doi.org/ 10.1016/j.ophtha.2014.05.013

[2] Kapetanakis V. V., Chan M. P., Foster P. J. [et al.] (2016). Global variations and time trends in the prevalence of primary open angle glaucoma (POAG): a systematic review and meta-analysis. British Journal of Ophthalmology, 100, 86-93.

[3] Avdeev, R. V., Aleksandrov, A. S., Bakunina, N. A. et. al. (2014). Model pervichnoy otkrytougolnoy glaukomy: manifestirovanie $\mathrm{i}$ ishody. Klinicheskaya meditsina, 12, 64-72.

[4] Chernyak, S. I., Ipatov, A. V., Moroz, O. N. (2013). Osnovni pokazniki invalidnosti ta diyalnosti mediko-sotsialnih ekspertnih komisiy Ukrayiny za 2012 rik. Analitiko-informatsiyniy dovidnik za red. direktora Departamentu reform ta rozvitku medichnoyi dopomogi MOZ Ukrayini M. K. Hobzeya, 149.

[5] Dmitrieva, E. I., Kim, T. Yu., Konkina, D. I., Pytel, N. O. (2014). Sovremennyi vzglyad na etiopatogenez pervichnoy otkrytougolnoy glaukomy. Meditsina i obrazovanie v Sibiri, 3. Available at: http://ngmu.ru/cozo/mos/article/text_full.php?id=1383

[6] Tikunova, E. V. (2013). Molekulyarnyie osnovy etiopatogeneza pervichnoy otkrytougolnoy glaukomy. Nauchnyie vedomosti. Seriya Meditsina. Farmatsiya, 11 (154), 161-165.

[7] Shepelyuk, G. G., Shepelyuk, G. S. (2010). Individualniy pidhid u pidbori mistsevih gipotenzivnih zasobIv dlya likuvannya pervinnoyi vidkritokutovoyi glaukomi. Visnik VDNZU «Ukrayinska medichna stomatologichna akademiya», 10 (2), $121-123$.

[8] Erichev, V. P., Egorov, E. A. (2014). O patogeneze pervichnoy otkrytougolnoy glaukomy. Vestnik oftalmologii, 6, 98-104.

[9] Serdyuk, V. M. (2014). Kliniko-eksperimentalne obgruntuvannya neyroprotektsiyi v kompleksI likuvannya hvorih na pervinnu vidkritokutovu glaukomu. 314

[10] Kirilenko, M. Yu., Churnosov, M. I. (2014). Geneticheskie issledovaniya pervichnoy otkrytougolnoy glaukomy. Vestnik TGU, 19 (4), 1140-1142.

[11] Abu-Amero, K., Kondkar, A., Chalam, K. (2015). An Updated Review on the Genetics of Primary Open Angle Glaucoma. International Journal of Molecular Sciences, 16 (12), 28886-28911. doi: http://doi.org/10.3390/ijms161226135

[12] Loomis, S. J., Kang, J. H., Weinreb, R. N., Yaspan, B. L., Cooke Bailey, J. N., Gaasterland, D. et. al. (2014). Association of CAV1/CAV2 Genomic Variants with Primary Open-Angle Glaucoma Overall and by Gender and Pattern of Visual Field Loss. Ophthalmology, 121 (2), 508-516. doi: http://doi.org/10.1016/j.ophtha.2013.09.012

[13] Ng, S. K., Casson, R. J., Burdon, K. P., Craig, J. E. (2013). Chromosome 9p21 primary open-angle glaucoma susceptibility locus: a review. Clinical \& Experimental Ophthalmology, 42 (1), 25-32. doi: http://doi.org/10.1111/ceo.12234

[14] Gibson, J., Griffiths, H., De Salvo, G., Cole, M., Jacob, A., MacLeod, A. et. al. (2012). Genome-wide association study of primary open angle glaucoma risk and quantitative traits. Molecular Vision, 18, 1083-1092.

[15] Kasthurinaidu, S. P., Ramasamy, T., Ayyavoo, J., Dave, D. K., Adroja, D. A. (2015). GST M1-T1 null Allele Frequency Patterns in Geographically Assorted Human Populations: A Phylogenetic Approach. PLOS ONE, 10 (4), e0118660. doi: http:// doi.org/10.1371/journal.pone.0118660

[16] Yu, Y., Weng, Y., Guo, J., Chen, G., Yao, K. (2013). Association of Glutathione S transferases Polymorphisms with Glaucoma: A Meta-Analysis. PLoS ONE, 8 (1), e54037. doi: http://doi.org/10.1371/journal.pone.0054037

[17] Silva, C. T. X., Costa, N. B., Silva, K. S. F., Silva, R. E., Moura, K. K. V. O. (2014). Association between primary open angle glaucoma and genetic polymorphisms GSTM1/GSTT1 in patients from Goiânia Central-West Region of Brazil. Genetics and Molecular Research, 13 (4), 8870-8875. doi: http://doi.org/10.4238/2014.october.31.2

[18] Josephy, P. D. (2010). Genetic Variations in Human Glutathione Transferase Enzymes: Significance for Pharmacology and Toxicology. Human Genomics and Proteomics, 2 (1). doi: http://doi.org/10.4061/2010/876940

[19] Rocha, A. V., Talbot, T., Magalhaes da Silva, T., Almeida, M. C., Menezes C. A., Di Pietro, G. et. al. (2011). Is the GSTM1-null polymorphism a risk factor in primary open angle glaucoma? Molecular Vision, 17, 1679-1686.

[20] Nowak, A., Majsterek, I., Przybyłowska-Sygut, K., Pytel, D., Szymanek, K., Szaflik, J., Szaflik, J. P. (2015). Analysis of the Expression and Polymorphism ofAPOE, HSP, BDNF,andGRIN2BGenes Associated with the Neurodegeneration Process in the Pathogenesis of Primary Open Angle Glaucoma. BioMed Research International, 2015, 1-14. doi: http://doi.org/ $10.1155 / 2015 / 258281$ 